\title{
Changing higher education
} policies: From the deinstitutionalization to the

\section{reinstitutionalization of the research mission in Polish universities}

\author{
Marek Kwiek* \\ Center for Public Policy Studies, Poznan University, ul. Szamarzewskiego 89, 60-569 \\ Poznan, Poland. \\ *Corresponding author.kwiekm@amu.edu.pl.
}

\begin{abstract}
This paper analyzes changing higher education policies in Poland in the last two decades. It argues that top Polish public universities became divided, with different individual academic and institutional trajectories in the academic fields in which educational expansion occurred (social sciences) and in fields in which it was much less pronounced (natural sciences). Using the concepts drawn from new institutionalism in organizational studies, this paper views the 1990s as the period of the deinstitutionalization of traditional academic rules and norms in public universities, with growing uncertainty about the core of the academic identity. In the expansion era (1990-2005), prestigious public research universities became excessively teaching-oriented. In the period of educational contraction, their currently teaching-oriented segments are expected to become research-intensive. New legislation grounded in an instrumental view of higher education is interpreted as a return to a traditional academic normative consensus, with increased emphasis on, and funding for, the research mission.
\end{abstract}

Keywords: university research mission; deinstitutionalization; normative institutionalism; higher education reforms; knowledge production; Poland.

\section{Introduction}

This paper analyzes changing higher education policies in Poland in the last two decades. It claims that the processes of the deinstitutionalization of traditional academic rules, norms and habits in the public sector were closely linked to the individual and institutional focus on teaching prevalent in the expansion era of Polish higher education (1990-2005), and in particular are linked to the dramatic growth of the private sector in higher education combined with the legal opportunity for academics from the public sector to hold multiple (full) employments. It argues that prestigious Polish public universities, after about 15 years of the coexistence with the demandabsorbing and teaching-oriented private sector, became fundamentally divided institutions. The paper discusses different (both individual academic and institutional) trajectories in knowledge production and research output in those academic fields in which substantial educational expansion occurred (social sciences) and in those fields in which educational expansion was much less pronounced (natural sciences).

This paper shows that traditional academic rules and norms in top public universities, according to which research was of key importance to the academic enterprise, were gradually weakening throughout the 1990s in the expansion-related, soft academic fields. The price of this process of weakening of traditional academic rules in soft (as opposed to hard) fields for top public universities was, however, high. It was the prolonged institutional (as well as individual academic) focus on the teaching mission, at the expense of the research mission which becomes crucial 
in a new wave of reforms. The empirical data studied include internationally visible publications across different disciplines (from a Central European perspective) and research-related academic promotions in Poland in different fields, both changing over time. In the post-Communist expansion era, prestigious public research universities became much more teaching-oriented, especially in soft disciplines, than could ever have been expected judging from their traditionally elite and Humboldtian character. In the coming contraction era (projected for demographic reasons to last until 2025 and beyond), with new legislation in force since 2011, policymakers expect the teachingoriented segments of public universities to become much more research-intensive. Low research engagement in the past two decades in the social science segments of higher education institutions may be a substantial obstacle to the implementation of current reforms, leading to institutions which are heavily differentiated by the research intensity of their major components. The policy challenge today is to implement new governance and funding approaches to institutions which are internally divided by institutional cultures which place different emphases on their research mission.

Using the concepts drawn from new institutionalism in organizational studies, the present paper views the 1990s as the period of the gradual deinstitutionalization of traditional academic rules and norms in public universities, with growing uncertainty about which academic behaviors were legitimate and which were not, and what was the core of the academic identity in research universities. The deintitutionalization processes were mainly concentrated in soft academic fields, in particular those which were in high social demand and which provided additional multiple employment opportunities in the expanding private sector. Recent higher education legislation reinstitutionalizes temporarily suspended (from a longer, historical perspective) traditional rules and norms and its implementation is viewed as the beginning of a transformation from one order into another. It introduces new governance and funding principles, redefines the academic career ladder and presents a new rationale behind public support for both teaching and research. Current government-produced, instrumental views (Maassen and Olsen 2007), expressed in practical terms in the new law of March 2011, seem to bring the research and teaching missions in top universities back to a healthy balance, much needed in knowledgedriven economies in which the role of university knowledge production is growing (Bonaccorsi and Daraio 2007, Kwiek 2012b, see the role of what Dill and Van Vught (2010) termed 'academic research enterprise').

The rest of this paper is as follows: Section 2 provides an analytical framework; Section 3 provides empirical background to the main claims of the paper: in particular, it refers to the international visibility of research production in Polish universities in soft and hard academic fields and to changing academic promotion patterns by academic fields; Section 4 discusses Polish reforms in the context of institutional and instrumental views of the university and Polish universities becoming instruments for national political agendas in the last wave of reforms; and Section 5 presents brief conclusions.

\section{Analytical framework}

The present study makes analytical use of three interrelated notions coming from students of institutional change, particularly from new institutional theory in political sciences: these are institutionalization, deinstitutionalization and reinstitutionalization (see March and Olsen 1989; Peters 1999; Deephouse and Suchman 2008). The study links these notions to a changing balance between university teaching and research missions in most prestigious Polish universities in 1990-2010 in hard and soft academic fields. Institutionalization, deinstitutionalization and reinstitutionalization as theoretical notions have not been used to study changes in higher education and in higher education policies, and certainly have not been referred to changing academic cultures in expanding post-Communist Central European systems. The paper uses a normative institutional approach to view the two decades of university transitions in Poland from the perspective of changing academic norms, rules, and behaviors.

For March and Olsen (2006a: 690), constitutive rules structure institutional behavior, rules prescribe what is appropriate action:

...to act appropriately is to proceed according to the institutional practices of a collectivity, based on mutual, and often tacit understanding of what is true, reasonable, natural, right, and good.

Basic logic of action in institutions is rule-following, and models assuming 'logic of appropriateness' are contrasted with models assuming 'logic of consequentiality' (see Peters 1999). Institutionalization as a process includes the following three dimensions: increasing clarity and agreement about behavioral rules, increasing consensus concerning how behavioral rules are to be described, explained and justified, and increasing shared conceptions of what legitimate resources in different settings are and who should have access to, or control over, common resources (Olsen 2010: 127). Deinstitutionalization, in contrast, implies that:

... existing institutional borders, identities, rules and practices, descriptions, explanations, and justifications, and resources and powers are becoming more contested and possibly even discontinued. There is increasing uncertainty, disorientation, and conflict. (Olsen 2010: 128)

And, finally, reinstitutionalization implies, inter alia:

... a transformation from one order into another, constituted on different normative and organizational principles. (Olsen 2010: 128) 
Deinstitutionalization, as Scott notes, refers to processes by which 'institutions weaken and disappear', as well as to such phenomena as 'enfeebled laws', 'diluted sanctions', 'increasing noncompliance', 'eroding norms', 'diminished force of obligatory expectations', 'the erosion of cultural beliefs and the increasing questioning of what was once taken for granted' (Scott 2008: 196; see also Djelic and Quack 2008: 301-4). Indicators employed to assess the extent of deinstitutionalization range from 'weakening beliefs to abandonment of a set of practices' (Scott 2008: 198; the scale of the deinstitutionalization of the research mission in Polish universities can be measured only indirectly, through proxy indicators: the abandonment of some traditionally 'taken-for granted activities', in our case, research activities, will be shown through empirical data in Section 3). Deinstitutionalization, as defined in a seminal study by Oliver (1992) is:

... a process by which the legitimacy of an established or institutionalized organizational practice erodes or discontinues. Specifically, deinstitutionalization refers to the delegitimation of an established organizational practice or procedure as a result of organizational challenges to or the failure of organization to reproduce previously legitimated or takenfor-granted organizational actions. (Oliver 1992: 564)

Institutionalized organizational practices can 'fall into disfavor or disuse' (Oliver 1992: 566). Section 3 presents empirical proxy indicators showing that the academic community's beliefs in research being a core university activity were gradually weakening in the post-Communist period, that research activities leading to international research output as an institutionalized organizational practice was eroding, and Polish universities as organizations were largely unable to reproduce their previously taken-forgranted (research-related) actions. For some time, especially in soft academic areas, major research-related sets of practices (viewed through the proxy indicators of internationally visible publications and research-based steps taken in career ladders across disciplines) were widely questioned. In the academic imagination, teaching-related sets of organizational practices replaced previously well-established research-related sets of organizational practices. Of the three pressures that can lead to deinstitutionalization (political, functional, and social), the social pressures are most useful for the present analyses and come closest to Olsen's normative-oriented approach to deinstitutionalization. Social pressures lead members of the organization to discard (some) institutionalized practices; increasing normative fragmentation means a loss of consensus on the 'meanings and interpretations that they attach to ongoing organizational tasks and activities' (Oliver 1992: 575). There is also an increasing 'erosion of institutionalized rules through a declining normative consensus and cognitively shared systems of meaning' (Djelic and Quack 2008: 302).

It is analytically useful to apply the above three notions to Polish prestigious research universities as institutions constituted by, or based on, normative and organizational rules and codes of behavior. Deinstitutionalization in the present paper is specifically linked to the first decade and a half (the expansion era, 1990-2005) of the postCommunist transition period. The shock of the transition from a centrally-planned to a market economy was mirrored in the university sector by growing institutional uncertainty and disorientation. The relatively stable world of the Communist period balance in teaching and research missions in Poland (as opposed to most other countries in the region in which research was exiled to newly created Soviet-type Academies of Sciences) was shattered, and universities were given institutional autonomy. The expansion era, with dramatically increasing enrollments which meant dramatically increasing non-core non-state feebased income, led to the growing role of teaching-related funding: student fees from part-time students in the public sector, student fees from all students in the private sector, and parallel employment opportunities (or academic moonlighting) for academics from public, especially prestigious, universities.

In the expansion era, there were ever more students in both sectors, and an estimated $30-40 \%$ of academics (and about $70-80 \%$ of professors) from the public sector in soft fields held parallel employment in the private sector, to make use of opportunities when they arose and to be able to maintain middle class standards of living while university salaries were falling behind the salaries of other professionals. All institutions, including research universities, became teaching-focused in their soft fields. The traditional academic norms and codes of behavior which stressed the role of research for individual career progression and for institutional development were widely questioned by the academic community, more in practice than in theory, and traditional research-based academic identities were contested. The force of obligatory research expectations from the academic community was diminishing. The changes in the academic approach to the research mission of prestigious universities - studied through the concept of deinstitutionalization - meant exactly 'diluted sanctions' and 'increasing noncompliance' with the unwritten post-World War II academic norm that research was the core of the academic enterprise in prestigious universities (Clark 1987). That norm was 'eroding' and beliefs in research as a set of core academic practices were 'weakening'. 'What was once taken for granted' was increasingly being questioned, both individually by academics and institutionally by universities. Prestigious universities were no longer able, or willing, or both, to provide proper legitimation for an established organizational practice of academic research. They failed as organizations to reproduce "previously legitimated or taken-for-granted organizational actions'. Social (and especially peer academic) pressures on being involved in research were low, the 'erosion of institutionalized rules' was caused by a 'declining 
normative consensus' about what constituted the core of academic activities in top universities.

The reinstititutionalization of academic norms and codes of behavior in the present paper is linked to reform initiatives following 2005, and, in particular, a coherent reform program of 2010-11, marked by a set of six laws of 2010 reforming the research sector and a new law on higher education of 2011. The processes of deinstitutionalization of the research mission in Polish universities coincided with the social and economic instabilities of the transition period in the Polish economy in the 1990s, started by 'shock therapies' leading to the market economy, and coincided with the expansion era in Polish higher education. The processes of reinstitutionalization now coincided with the period of a well-settled market economy model, combined with the political stability achieved through EU membership and the contraction era already felt in Polish higher education and expected to be in full swing, for demographic reasons, in the coming years.

The processes of deinstitutionalization of traditional academic norms, habits and codes of behavior in large (soft) segments of the public sector are closely linked to the mostly monetary opportunities provided to the academic community by the expansion era: the dramatic growth of private higher education and of fee-based part-time teaching in the public sector (Kwiek 2011a, 2010). We argue that traditional rules of higher education (authoritarian, communist, ideological but still very much Humboldtian in Poland) were weakening throughout the 1990s and a sort of academic normative vacuum (Olsen's 'uncertainty, disorientation, and conflict') appeared in the higher education sector. In this normative vacuum, all sorts of codes of academic behaviors and rules and norms of academic conduct, unthinkable a few years earlier, suddenly became academically acceptable.

In the expansion period, those academics in prestigious universities who were abandoning the research university mission, changing their working habits and refocusing on external, additionally-paid teaching did not risk exclusion from the academic community. Clearly, what had been prestigious about top public universities was gradually being lost, and the international research visibility of Polish academics in arts and humanities, social sciences, economics, business and finance was dramatically decreasing. By contrast, hard academic fields continued to perform well or very well, despite the financial austerity prevalent in public universities. Recent reforms tend to reestablish the research focus of top public universities, and within them, to decrease the knowledge production gap between hard and soft disciplines that had emerged in the expansion era. For this purpose, reforms use what Maassen and Olsen term 'instrumental' logic, rather than the 'institutional' logic, discussed in Section 4.

We argue that the dramatic growth of private higher education in the 1990s was made possible by the gradual deinstitutionalization of traditional academic norms, codes of behavior, and habits in (soft academic areas of) public universities which made academic moonlighting by its faculty perfectly acceptable, both individually and institutionally. Large-scale multiple employment of the academic profession for about a decade became the (academic) norm, not the exception. The price to be paid by the Polish higher education system as a whole was however, high. The gradual individual and institutional refocusing on teaching, at the expense of research, increasingly led to a long-term knowledge production-based isolation from the international research community, as we shall show in empirical terms in Section 3. Traditional academic norms which sanctioned the crucial role of research activities in prestigious universities were temporarily suspended: academics relieved from 'taken-for-granted' duties eagerly focused on large-scale, profit-driven teaching. The suspension period, referred to as the deinstitionalization period, lasted until the 2010-11 wave of reforms which may be interpreted as a government-inspired (rather than driven by academics) legal call to return to a traditional academic normative consensus about what top public universities should be doing and why. Recent reforms seem to complete the period of the (temporary) suspension of academic norms and codes of behavior, valid only for the economic transition and educational expansion period. They attempt, among many other things, to bring back the research dimension in top public universities, providing both individual and institutional funding and career progression mechanisms related to individual and institutional, measurable, preferably international, research output. Traditionally, the role of research in post-World War II Western academia was clearly defined: as Clark (1987: 102) formulated it:

... it is research, as a task and as a basis for status, that makes the difference.... The minority of academics who are actively engaged in research lead the profession in all important respects. Their work mystifies the profession, generates its modern myths, and throws up its heroes.

The new law through its new, highly competitive funding mechanisms reminds the (somehow surprised) academic community about the crucial role of research in top national universities. The reform package of 2010-11 is viewed here as the reinstitutionalization of the research mission in Polish universities, or (in Olsen's terms) as '...a transformation from one order into another, constituted on different normative and organizational principles. (Olsen 2010: 128)'.

\section{Empirical background: soft and hard fields, or the divided university}

This section is intended to provide an empirical background to general claims about inter-disciplinarily 
divided universities and their contribution to global knowledge production. There are no direct indicators to refer to processes of deinstitutionalization of the research mission in universities. We suggest using proxy indicators with which to 'measure' the scale of the changes. We shall compare the internationally visible knowledge production in different academic disciplines in Polish universities and compare the research engagement of Polish academics across different academic disciplines. Comparisons with both Central Europe and the wider Europe, in time and across disciplines, will be made. In Poland in the post-Communist expansion era, the rules constituting the heart of the institution of the modern research university were not followed, and this not-following was not sanctioned. Dozens of thousands of academics from public universities, especially those that were prestigious, and especially in the social sciences and the humanities, economics, business and finance, were engaged full-time in additional paid teaching in emergent private institutions or in their own institutions (for fee-based part-time students), or both. Their average combined teaching workloads were breathtaking.

In general, there are several determinants of research productivity in universities, some endogenous and some exogenous to the higher education system. These include: overall levels of national research funding, its competitiveness and its private/third-stream share (Aghion et al. 2008; Lepori et al. 2007); university autonomy and governance structures (Aghion et al. 2009; Kwiek 2012a, 2012b); national university traditions and geographical location of institutions (Palfreyman and Tapper 1999); as well as exogenous factors related to what Porter et al. (2008) call 'pillars of competitiveness'. The case of Central Europe is considered by Kwiek (2011b, 2012a; see also Porter et al. 2008). But the present study focuses on the negative impact of heavily increased teaching loads (in public and private institutions combined, for many academics holding down parallel jobs) on the academic culture, in particular on the institutional research mission. The link between academic knowledge production in a group of Poland's most prestigious higher education institutions (all public institutions legally defined as 'universities' and 'polytechnics', 34 in total) and teaching loads was recently confirmed through empirical research based on microeconomic data from individual institutions. As Wolszczak-Derlacz and Parteka (2010: 64) conclude:

... there is a clear negative correlation between the number of students per academic staff member and the number of publications in ISI Web of Science per academic staff member ... we can conclude that research activity and didactics are indeed rather competitive than complementary.

As Bonaccorsi and Simar pointed out (2007: 166) when discussing what they termed the 'trade-off between teaching and research': 'teaching and research bear upon a limited time budget of academic staff'. In a specific
Polish case, academics in soft disciplines had much higher average (combined in both sectors) teaching loads than their Western European colleagues. The scale of (perfectly legal, and with no restrictions until 2010) multiple employment in Poland has been massive and its disciplinary concentration reflects the disciplinary concentration of private higher education (and part-time fee-based teaching in home public institutions). The data from the private sector show that in 2010, out of 17,136 full-time employed academics, only 503 (or less than $0.03 \%$ ) indicated employment in a given private institutions as their 'basic workplace'. For $99.9 \%$ of academics working in the private sector, employment in this sector was additional to employment in the public sector. As ministerial data from 2008 show, in the category of full professors, $37 \%$ were full-time employed in one additional institution and $3 \%$ in two additional institutions. In total, $40 \%$ of all full professors held multiple employments. However, the data do not show the scale of part-time additional employment, and refer to all academic disciplines. This means, in practical terms, that perhaps $70-80 \%$ of all full professors from the selected soft disciplines in which the private sector was concentrated were holding multiple employment. In fact, in the vast part of the academic profession, teaching was where the action was: academic cultures were changed, with measurable negative consequences of the teaching focus of the academic profession on research productivity.

We shall refer here to two consequences in two areas: in research output and in academic promotion patterns. Today, Polish university-based knowledge production seems low from a European perspective. A simple bibliometric analysis (performed on the basis of the SCImago Journal \& Country Rank dataset that includes the journals and country-scientific indicators developed from the information contained in the Scopus database, and referred to the 1996-2010 period; for the improvement of its subject classification, see Gómez-Núnez et al. 2011: 753-8) demonstrates a powerful disciplinary divide in Polish universities between hard and soft fields. (Results of analyses based on the commercial ISI Web of Science database should not be markedly different as we refer to general regional trends in the production of internationally visible publications). Instead of analyzing Polish research output in all academic fields, we will focus on the strongest and the weakest fields in the last 15 years, from global and regional (Central European) comparative perspectives, using the number of internationally recognized publications in a field as a proxy indicator for the research engagement of academics in a given field in the countries studied. Higher research engagement in a given field in a given country should tend to mean more internationally visible publications originating from that country. We shall now analyze the possible measurable (and still indirect, as no direct causal links can be shown) effects of the devalorization of the research mission in Polish universities and show a growing powerful disciplinary 
divide within public universities, with which Polish higher education will have to cope in the coming years.

The three strongest academic fields throughout the 1996-2010 period have been physics and astronomy, mathematics, and chemistry (globally ranked 13, 13, and 14, respectively, in 2010, by the number of publications; we disregard here a further disaggregation between publications originating from universities and from research institutes, for the sake of simplicity). In 1996, these three fields were globally ranked roughly in the same, relatively high positions (13, 15, and 12, respectively). The weak fields, in contrast, include arts and humanities, social sciences, and economics, econometrics, and finance, ranked relatively low in $2010(39,39$, and 37, respectively). In 1996, two of the three fields (arts and humanities, and social sciences) were ranked much higher $(24,24$, respectively; the third field was 37). We study here the trajectory of the internationally visible research output in the last 15 years, by strong and weak fields of research, in comparison with three much smaller systems which were also undergoing post-Communist transitions: the Czech Republic, Hungary and Slovakia. We do not make a direct comparison of the total research output of the four countries in these academic areas and we do not control the data for the size of the academic profession. We merely compare the trajectories in the period 1996-2010 in two distinct groups of academic areas (strong performers and weak performers). The strong and the weak research performers in 2010 coincide with the scale of involvement in additional fee-based teaching in the last two decades, and apparently different normative views on a healthy teaching/research balance in prestigious universities. Strong research performers followed traditional academic rules and norms while weak (and weakening) performers eagerly used the teaching opportunities provided by the expanding public and private sectors.

There are many reasons why, in general, the natural sciences and related fields were able to maintain their relatively high position both in the global and regional (Central European) knowledge production in 1996-2010 and why, by comparison, the social sciences and related fields performed much worse. One of them, we claim here, is the individual academic and institutional focus on teaching and the teaching mission, and the individual academic and institutional devalorization of research and the research mission in faculties of arts and humanities, social sciences and economics, and related areas in most prestigious Polish universities in which both research funding and research production have been heavily concentrated. The private sector, demand-absorbing and almost fully teaching-oriented, has been focused on selected high-demand low-cost fields only: the share of the 'social sciences, economy and law' OECD category was almost $75 \%$ in 2000 , and the share of 'science' was below $5 \%$ (by 2010 , it has decreased to about $54 \%$ and increased to about $5.5 \%$, respectively). Also in the public sector, the biggest growth in enrollments occurred in the same soft fields: throughout the 2000 s, more than $60 \%$ of enrollments were in three fields: social sciences, economy and law, humanities and arts, and education.

In those fields in which massive expansion occurred, Poland has significantly lost its international research visibility, from both global and regional perspectives. While in the global ranking (all fields), Poland moved down the ladder from rank 16 (1996) to rank 18 (2003) to rank 20 (2010), its still relatively good position is due mostly to those fields in which academics and departments had virtually no opportunities to focus on additional paid teaching, especially no opportunities for multiple employment in the private sector. No private higher education institution lured academics from Polish universities in fields such as chemistry, physics, astronomy and mathematics, the four fields ranked highest globally.

From a regional perspective (compared with the Czech Republic, Hungary and Slovakia), not surprisingly, given the size of higher education and research systems, Poland's chemists, physicists and astronomers, and mathematicians published more international papers than their colleagues from the three other countries combined both in 1996 and in 2010, see Fig. $1 .^{1}$ Their publications accounted for $55.7 \%$ (in 1996) and 54.3\% (in 2010) of all publications from the four countries. The supremacy of Polish academics, in statistical terms, has been maintained throughout the period, as shown in Fig. 1 (in 1996, there were 4,295 Polish publications in a pool of 7,717 coming from the four countries; in 2010, the numbers were 8,600 and 15,827 , respectively).

What is important for us here, though, is the crosscountry differences in national research outputs in 1996-2010 in soft, expansion-linked fields. Data show (see Fig. 2) that research output in those fields (in which private higher education and part-time teaching expanded), as opposed to hard fields, has been decreasing systematically compared with the research output of regional competitors. In 1996, in soft areas, the share of Poland's research output in the output from the region was relatively high in both arts and humanities $(55.6 \%)$ and in social sciences $(48.8 \%)$ (it was much lower $(23.8 \%)$ in economics and related areas). In 2010, in the arts and humanities, the number of internationally visible publications from Poland was only about half the number of the publications by their colleagues from the Czech Republic and Hungary, and only slightly more than those from Slovakia (Polish publications in the arts and humanities accounted for only about $23 \%$ of all publications from the four countries). In the social sciences, the total number of internationally visible publications by Polish, Czech and Hungarian academics was about the same. In economics and related areas the Polish research output was much lower than the Czech one. But, at the same time, the Polish higher education and research systems are huge by comparison. (Poland had more academics 


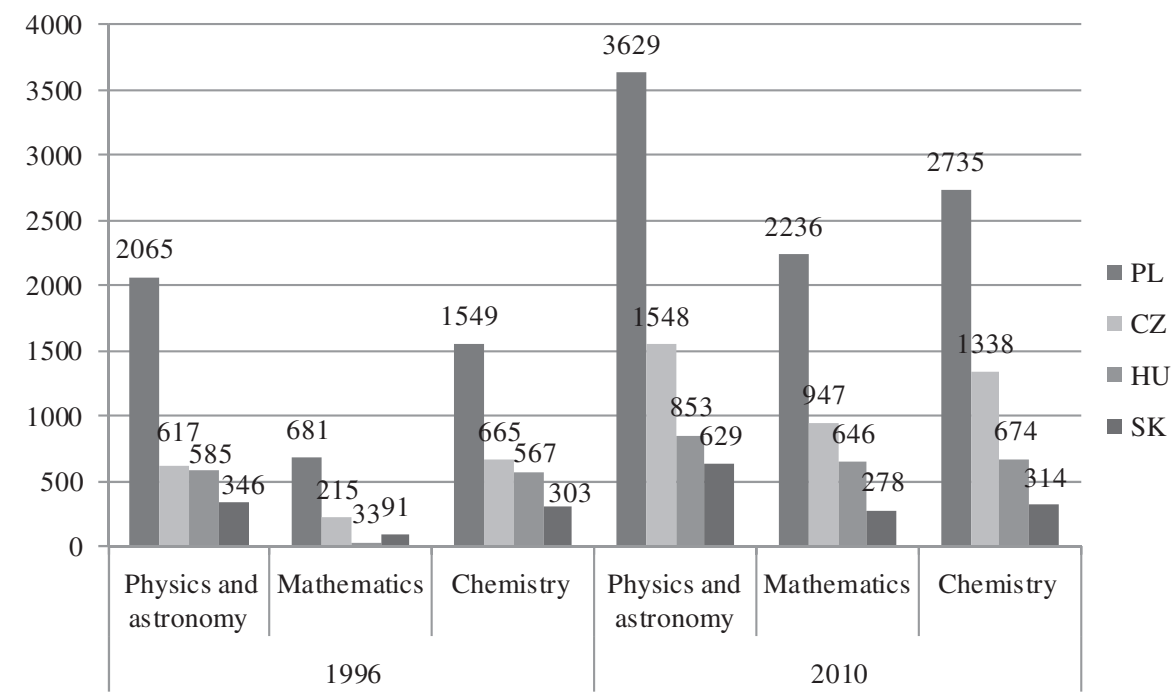

Figure 1. Number of publications in academic fields of 'physics and astronomy', 'mathematics' and 'chemistry' by country for 1996 and 2010 (author's own calculations based on data from SCImago Journal \& Country Rank 2012).

Note: PL Poland, CZ Czech Republic, HU Hungary, SK Slovakia.

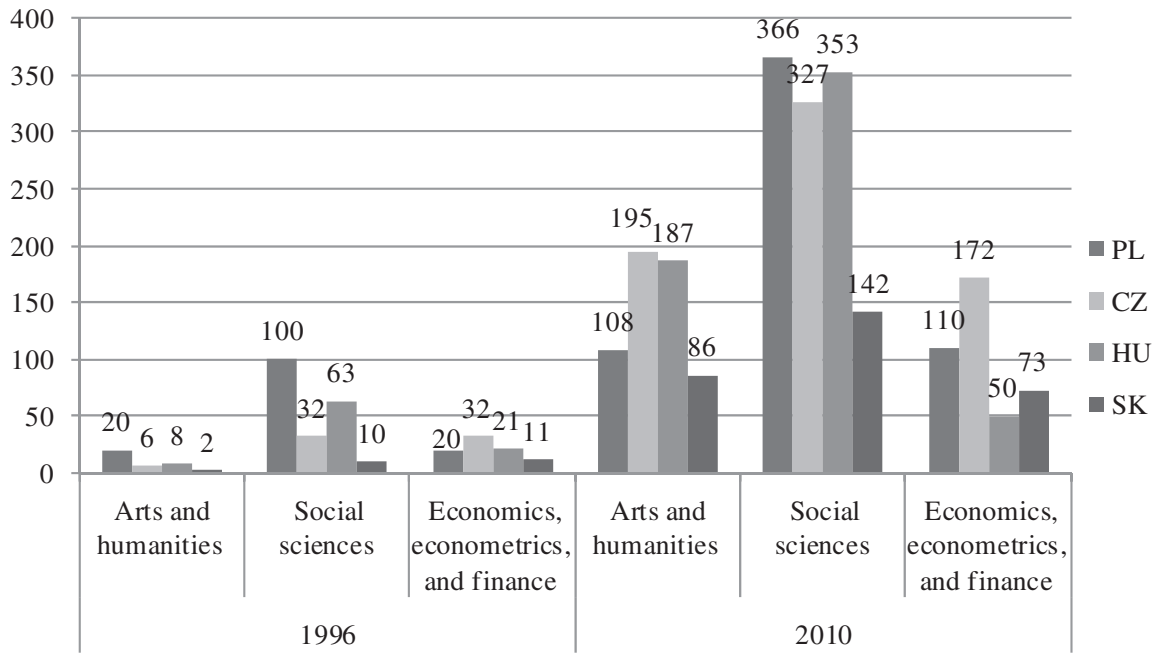

Figure 2. Number of publications in academic fields 'arts and humanities', 'social sciences' and 'economics, econometrics and finance', by country for 1996 and 2010 (author's own calculations based on data from SCImago Journal \& Country Rank 2012). Note: PL Poland, CZ Czech Republic, HU Hungary, SK Slovakia.

than the three other countries combined throughout the 1996-2010 period which was clearly reflected in the research output in 1996 in all areas.) In soft areas, Poland in 2010 was clearly lagging behind its regional competitors: while in 1996, there were 140 Polish publications in a pool of 325 coming from the four countries, in 2010, there were only 584 publications in a pool of 2169 . The slide in the Polish share in soft academic areas was from $43 \%$ to $26.9 \%$ in the period studied, as shown in Table 3 ). The details for the period 1996-2010 for both soft and hard academic areas are given in Tables 1 and 2.

Thus, in the period analyzed, which coincided with the expansion of higher education in soft academic areas and with opportunities to hold multiple full-time and part-time jobs in these areas, hard academic fields managed to maintain their high positions (both globally and in the region) and soft academic fields noted a downward slide in their positions. In particular, the share of Polish publications in arts and humanities and in social sciences in publications coming from these four regional economies slid dramatically from $55.6 \%$ to $18.8 \%$; in the social sciences it slid from $48.8 \%$ to $30.8 \%$ in $1996-2010$ (see Table 3). Research productivity across academic areas and across the four regional higher education systems clearly shows that the soft areas in Poland were powerfully affected by the processes of deinstitutionalization of the research mission in universities.

Another proxy indicator to measure faculty research engagement across academic fields in the Polish case is the changing number of Habilitation (or postdoctoral) degrees 
Table 1. Number of publications in academic fields of 'arts and humanities', 'social sciences' and 'economics, econometrics and finance', by country (own calculations based on data from SCImago Journal \& Country Rank 2012)

\begin{tabular}{lrrrr}
\hline & $\begin{array}{c}\text { Poland } \begin{array}{l}\text { Czech } \\
\text { Republic }\end{array} \\
\end{array}$ & Hungary & Slovakia \\
\hline 1996 Arts and humanities & 20 & 6 & 8 & 2 \\
$\quad$ Social sciences & 100 & 32 & 63 & 10 \\
$\quad$ Economics, econometrics & 20 & 32 & 21 & 11 \\
$\quad$ and finance & & & & \\
2010 & 108 & 195 & 187 & 86 \\
$\quad \begin{array}{l}\text { Arts and humanities } \\
\text { Social sciences }\end{array}$ & 366 & 327 & 353 & 142 \\
$\quad$ Economics, econometrics & 110 & 172 & 50 & 73 \\
$\quad$ and finance & & & & \\
\hline
\end{tabular}

Table 2. Number of publications in academic fields of 'physics and astronomy', 'mathematics' and 'chemistry', by country (own calculations based on data from SCImago Journal \& Country Rank 2012)

$$
\begin{array}{ll}
\text { Poland } & \text { Czech Hungary Slovakia } \\
& \text { Republic }
\end{array}
$$

\begin{tabular}{|c|c|c|c|c|c|}
\hline \multirow[t]{2}{*}{1996} & Physics and astronomy & 2065 & 617 & 585 & 346 \\
\hline & Mathematics & 681 & 215 & 33 & 91 \\
\hline & Chemistry & 1549 & 665 & 567 & 303 \\
\hline \multirow[t]{3}{*}{2010} & Physics and astronomy & 3629 & 1548 & 853 & 629 \\
\hline & Mathematics & 2236 & 947 & 646 & 278 \\
\hline & Chemistry & 2735 & 1338 & 674 & 314 \\
\hline
\end{tabular}

Table 3. Share of Polish publications in selected hard academic fields ('physics and astronomy', 'mathematics' and 'chemistry') and selected soft academic fields ('arts and humanities', 'social sciences', and 'economics, econometrics and finance', combined, 1996 and 2010, in \% (own calculations based on data from SCImago Journal \& Country Rank 2012)

\begin{tabular}{lcc}
\hline Academic field & 1996 & 2010 \\
\hline Physics and astronomy & 57.2 & 54.5 \\
Mathematics & 66.8 & 54.4 \\
Chemistry & 50.2 & 54.0 \\
Arts and humanities & 55.6 & 18.8 \\
Social sciences & 48.8 & 30.8 \\
Economics, econometrics and finance & 23.8 & 21.4 \\
Selected hard academic fields (combined) & 55.7 & 54.3 \\
Selected soft academic fields (combined) & 43.0 & 26.9 \\
\hline
\end{tabular}

and professorship titles (full professor) awarded annually in Poland in the last decade. Both are awarded centrally (that is, independently of higher education institutions) and entirely on the basis of research achievements. As in the case of internationally visible publications, we shall demonstrate cross-fields differences between hard and soft disciplines.
In the period 1999-2010, the overall number of both Habilitation degrees and professorship titles had decreased, from 915 to 859 (by $6.12 \%$ ) and from 630 to 459 (by 27\%), respectively. In the same period the research community in all sectors of performance increased by about 22,000 researchers (or by $28 \%$, from 78,091 in 1999 to 100,151 in 2010). Both stable and decreasing number of Habilitations and professorships in an expanding system clearly indicate decreasing research engagement of the academic faculty in general. As in the case of publications, also in the case of the research-based academic promotions, Polish universities are heavily divided according to academic fields. We have contrasted again chemistry and physics on the one hand, as those fields in which holding multiple employments was not possible, with the humanities (which in the Polish statistics include also arts and social sciences) and economics, as those fields in which holding multiple employment was the general rule. The most striking difference between the former and the latter academic fields are in the number of professorships awarded in 1999 and 2010: while in chemistry and physics it has slightly increased (by 6-8\%), in the humanities it has decreased by over one-third (34.62\%), and in economics it has decreased by almost two-thirds $(62.79 \%)$. The data are given in Figs. 3-5).

The share of professorships awarded in chemistry of all professorships awarded increased substantially: from $3.49 \%$ to $5.22 \%$; for physics, the increase was from $4.92 \%$ to $7.18 \%$. In contrast, for the humanities, the decrease was from $16.50 \%$ to $14.81 \%$ and for economics from $6.82 \%$ to $3.49 \%$.

The above brief analysis of research-based promotions clearly demonstrates that there is a powerful disciplinary divide within Polish higher education, especially within prestigious universities which provide the vast majority of internationally visible publications and where the vast majority of full professors are employed. The devalorization of the research mission in research universities refers directly to those fields in which teaching expanded in both sectors. Both global and Central European comparisons in research production in 1995-2010 and inter-disciplinary comparisons of academic degrees awarded in Poland in 1999-2010 clearly show the soft academic fields as those in which the traditional academic norms ruling in prestigious universities failed.

Thus public universities in the post-Communist period have been increasingly becoming divided institutions, following different rules and engaging in different university missions. The taken-for-granted academic norms prevailing in research universities were suspended in several major academic fields (in soft disciplines) in the transition period of between a decade and a decade-and-a-half. The traditional 'logic of appropriateness' (March and Olsen 2006a) in research universities was weak and unable to stop the turning of huge individual and institutional energy into additionally-paid teaching, especially in the profit-driven, 
although nominally non-profit, private sector. All sorts of public justifications for, and rationales of, holding multiple academic posts were created throughout the expansion period. The massive involvement of academics in the development of private higher education led to the gradual devaluing of the research mission of public research universities where they kept their primary employment. From an institutionalist perspective, the 'logic of appropriateness' assumes that:

Rules are followed because they are seen as natural, rightful, expected and legitimate. Actors seek to fulfill the obligations encapsulated in a role, an identity, a membership in a political community or group, and the ethos, practices, and expectations of its institutions. (March and Olsen 2006a: 689)

The collapse of communism in general, and the emergence of the private sector combined with impoverishing salaries in public higher education in particular, made traditional academic rules and norms constituting research-based prestigious universities look no longer

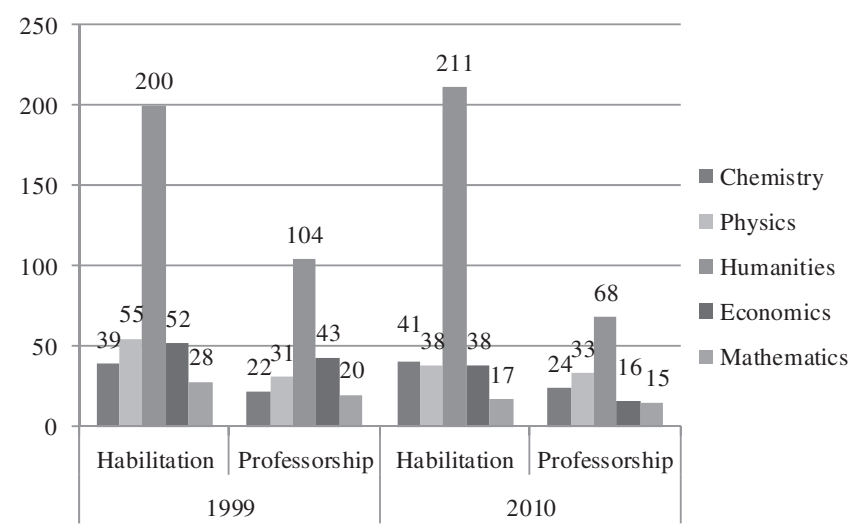

Figure 3. Number of Habilitation degrees and professorship titles in 1999-2010 in selected academic disciplines. natural, rightful, expected and legitimate. The rules and the norms were temporarily suspended. The expansion period was the period of the deinstitutionalization of traditional academic rules and norms constituting the essence of public research universities (and, despite heavy ideologization, prevalent under Communist rule), with uncertainty about which academic behaviors were legitimate and what was the core of the academic identity in top universities. One of the fundamental consequences of the large-scale phenomenon of the growth of the private sector in 1995-2005 was limited academic pressure on reforming public universities, including limited pressure on increasing academic salaries in the public sector. In that period salaries were extremely low but holding multiple posts in both public and private sectors was treated as a reasonable and academically acceptable survival strategy for the academic community.

The (temporary, from a historical perspective) suspension of traditional academic norms highly valuing research activities in top national institutions and the (temporary) acceptance of new academic codes of behavior, have contributed to the phenomenal growth of the private sector on the one hand and, on the other, to a substantial decline in the research performance of the public sector and its lost research aspirations, particularly in soft disciplines, as shown above. A (partially) self-imposed decrease in the research aspirations of the academic community in the 1990s has clearly led to a decrease in research funding: academics were a weak, divided interest group, both unable and unwilling to demand higher research funding. From the perspective of a regional comparison, while expenditures on R\&D as a share of gross domestic product (GDP) in 2000-10 increased in Poland only marginally (from $0.64 \%$ to $0.74 \%$ ), at the same time the increase in the Czech Republic was from $1.17 \%$ to $1.56 \%$, in Hungary from $0.81 \%$ to $1.16 \%$ and only in Slovakia was it marginally decreased (from $0.65 \%$ to $0.63 \%$ (Eurostat 2012)).

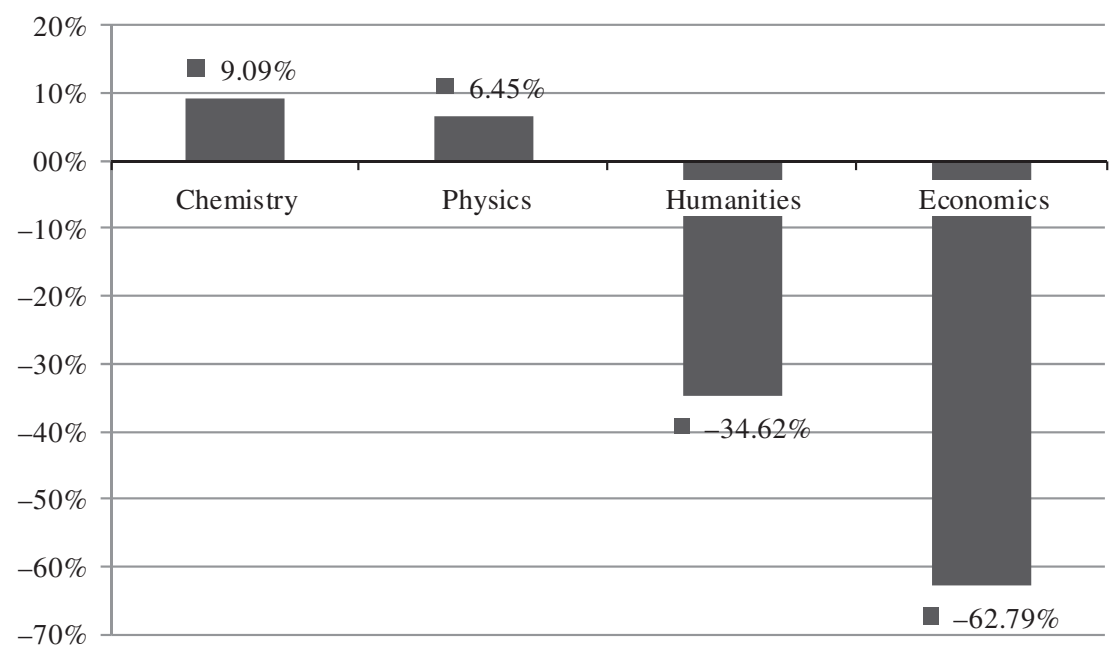

Figure 4. Change in number of professorship titles in 1999-2010 in selected academic disciplines (in \%). 


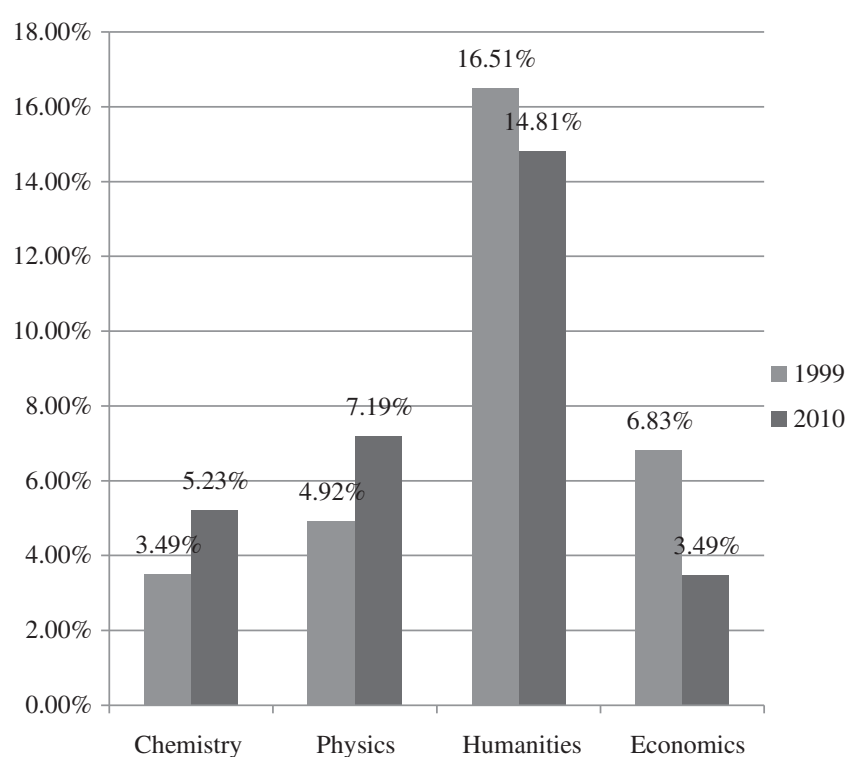

Figure 5. Change in share of professorship titles in all professorship titles awarded in selected academic fields, 1999 and 2010 (in \%).

One of the explanations of underfunding of research is a large-scale teaching focus of the university sector. Consequently, there have been too-mild academic pressures, especially organized pressures, on increasing public expenditures on research (the academic community should be one of powerful interest groups involved in the competition for public resources through lobbying efforts, see Tandberg (2010).

\section{Polish reforms: institutional and instrumental views of the university}

From a historical perspective, there was a single national policy emphasis for the higher education sector in Poland after it had been granted academic freedom and institutional autonomy in 1990: it was increasing access to higher education. The refocusing of soft fields in universities on teaching and their growing international isolation, including decreasing measurable international research output, were systematically ignored by policymakers. Relatively small-scale changes in public higher education in the period 1990-2005 have only recently been followed by large-scale changes in 2010-2011. New regulations culminated in an amendment to the 2005 Law (of 18 March 2011, generally regarded as a new law), which introduced new rules for the academic game: universities are increasingly becoming instruments for national political agendas and their research output plays an increasingly important role in future funding arrangements. Polish universities, after drifting for about two decades with the tide of the expansion period, are currently expected to undergo fundamental transformations in their missions, governance structures, and modes of funding. The overemphasis on teaching at most prestigious research institutions seems to be increasingly obsolete in the contraction period, with the number of students expected to decrease from about 1.8 million in 2011 to about 1.2 million in 2025 (Kwiek 2011a).

Recent reform packages introduced new rules for the academic game in which funding for research is strongly linked to measurable research output. In the current wave of reforms, a new model of competitive, mostly grantsbased research funding, disbursed by two new national research councils, administered by academics and independent of the state authorities (the NCN for fundamental research and the NCBiR for applied research) is being introduced. New mechanisms for allocating research funding are much more performance-based and aim to provide competitive individual or group research grants rather than institutionally-distributed subsidies for research. Nevertheless, national research funds as a share of GDP are increasing very slowly.

March and Olsen (2006b: 14) draw a distinction between incremental and fundamental changes, or 'changes within fairly stable institutional and normative frameworks' and 'changes in the frameworks themselves'. Central European transformations in higher education in the early 1990s clearly belonged to the radical, latter category, while transformations in the 2000s are more of the incremental, former category. But in the Polish case, recent reforms could have a potential for again changing 'the frameworks themselves'. They clearly indicate the construction of new institutional norms and new academic codes of behavior, intended to replace those that predominated in the expansion period.

Transformations of Polish universities can be viewed as resulting from several powerful, interrelated, internal and exogenous, pressures. First, there were internal pressures to continue with academic rules, norms, and organized practices inherited from the Communist period. Second, there were internal institutional pressures to survive in the turmoil of the economic 'shock therapies' of the beginning of the 1990s and beyond and in the midst of fundamental financial austerity (this is where the resource dependence perspective could be useful: as Pfeffer and Salancik (2003: 2-3) argue, 'the key to organizational survival is the ability to acquire and maintain resources', and this was crucial in the 1990s). And, third, there were internal and exogenous pressures to design new academic norms, rules and organized practices, responding to the guiding principles of the reforms in the early 1990s: academic freedom and institutional autonomy. Transformations of the universities in the 1990s were specific in kind, and distant from those ongoing in Western Europe at that time and in the previous decade (see Kwiek (2006) and, for a panoramic view of transformations in Western Europe, especially (Neave and van Vught 1991, 1994)). They led to the erosion of traditional rules and norms in large parts of Poland's top universities 
and to the questioning of established organizational practices in those areas which witnessed huge numerical expansion. The balance between teaching and research in soft disciplines was suspended in the 1990s and partly in the 2000 s, leading to a temporary devaluation of research activities.

Thus Polish universities in the early transition period found themselves in a temporary normative, social and cultural vacuum. Suddenly, academic institutions had to face huge organizational and financial challenges and had no detailed guidance to follow. In the 1990s, there were neither clear national policies nor clear national strategies in higher education. Inherited academic identities, norms, rules and habits, patterns of thinking and acting, routines, practices and academic ethos, were only useful in institutional survival strategies to some extent. Rule-following (traditional rules), for a decade-and-a-half, did not work, as the rules inherited from the Communist period were deemed obsolete, authoritarian, and anti-democratic. External shocks related to the 'post-Communist transition' in the economy and the financial austerity prevalent throughout the 1990s were driving the dynamics of institutional change. Universities were driven by expansion-related phenomena and academic institutions (and academics themselves) were responding in the way a resource dependence model expects them: seeking how to manage to survive, in the mutual processes of interaction between organizations and their environments (Pfeffer and Salancik 2003: 258-62), at both the micro-level of individuals and the meso-level of institutions.

We argue here that the new academic culture that emerged in the 1990s, with a major feature of the deinstitutionalization of the research mission, is still defining codes of academic behavior. In the 1990s, new, temporary patterns of academic behavior emerged and routines and practices which took root in institutions were decoupled from previous routines and practices. Research became heavily underestimated, at both the individual and the institutional level in the internal policies of top public universities, especially in soft academic disciplines. What is important for the future is that the norms, attitudes, and codes of behavior are changing very slowly, as empirical studies of the academic profession show. In a recent (2010) large-scale survey of the academic profession in Europe, Polish academics are very different from their colleagues from most Western European systems in their self-declared teaching/research preferences. ${ }^{2}$ Polish academics prefer research to teaching much less frequently than their Western European colleagues (only 11\% of them show their interest to be 'primarily in research', compared with Norway and Austria with 31\%, Finland with $29 \%$, Switzerland and the UK with $27 \%$ and Germany with $26 \%$. Poland has one of the lowest scores in Europe, together with Ireland with $9 \%$ and Portugal with $7 \%$, and slightly below Italy with $12 \%$ and the Netherlands with 14\%). The direction of future changes in the Polish academic profession is unclear but the 2010 attitudes, from a European perspective, do not favor research activities. ${ }^{3}$ The weakening of traditional rules (which in Polish research universities meant the Humboldtian combination of teaching and research) resulted from the coexistence of financially deprived public sector institutions and financially thriving private sector institutions, followed by the emergence of large-scale fee-paying studies in the public sector itself. The privatization of higher education led to a fundamental reconfiguration of which academic actions were believed to be 'appropriate, natural, and legitimate' (Olsen 2010: 127) in public universities. Essentially, the shadow of the austere 1990s and individual and institutional survival strategies of the 1990s continue to have a powerful negative impact on new generations of researchers.

A useful distinction between instrumental and institutional perspectives in viewing the university was offered by Maassen and Olsen (2007: 27). In an instrumental perspective, the university is involved in a 'set of contracts':

...support, economic and otherwise, depends on contributions. Change reflects a continuous calculation of relative performance and costs.

An institutional perspective, in contrast, assumes that well-entrenched institutions:

... reflect the historical experience of a community, that they take time to root and they are difficult to change rapidly and radically.

As an institution, the university is involved in a pact based on 'long-term cultural commitments'. The instrumental view of the university dominates most reform programs and debates, both at the European level and at national levels. Recent Polish reforms are a perfect example of the tensions between viewing the university as an institution (by the Polish academic community) and viewing it as an instrument for national political agendas (by the Polish government). In Poland, as well as throughout Europe, reform initiatives in higher education lead to new reform initiatives. As Brunsson commented, it with reference to all organizations in modern society:

...large contemporary organizations, whether public or private, seem to be under almost perpetual reform-attempts at changing organizational forms. (Brunsson 2009: 1; see also Brunssson and Olsen 1993)

Recent reform initiatives may be regarded as the beginning of a passage from one order to another order, with different normative (and organizational) principles (Olsen 2008: 9), or as reinstitutionalization processes relevant for the post-expansion era in which the role of research at both individual micro-levels and institutional meso-levels in prestigious universities grows substantially. The ministerial documents defining the 'basic assumptions' of the reform show the extent to which the new order is potentially 
different from the previous one. There are six major weaknesses in Polish higher education to which new legislation responds: no funding streams awarded to universities directly on the basis of high quality teaching and research; low levels of internationalization of studies; the inadequate structure of study programs, with huge overrepresentation of the social sciences and educational sciences; complicated career ladders for academics; obsolete management modes; and weak links between universities and their socio-economic environments. The reform is intended to have an impact on all six areas.

Polish public higher education is still operating according to the traditional Humboldtian rules of the game, i.e. the rules of the university understood as a 'rule-governed community of scholars' (Olsen 2007: 29-31), with an important difference discussed throughout the paper: the programmatic micro- and meso-level focus on teaching and teaching-related resources. While in Western European systems the coexistence of different models (the traditional institutional model and various of Olsen's instrumental models in which the university is merely a tool for different purposes) prevails, in Poland reforms are intended to replace a ruling traditional model, transformed only marginally in the last 20 years, with Olsen's model of the university as an 'instrument for national political agendas'. A shift in policy thinking and in new legislation has a clear direction: away from a faculty-centered model (with academic freedom represented, inter alia, in the form of the consistent disregard for the research mission in internally divided, mission-differentiated universities), and towards a model in which the university's role is to consistently follow national political agendas (with a growing emphasis on research in ever more concentrated areas and institutions, according to strict national governmental priorities). Surprisingly, while all other public sector services are increasingly being reconceptualized towards market-like models (Kwiek 2007), public higher education seems to be reconceptualized as a new tool for national political agendas, with surprisingly limited encouragement to be more market-oriented.

Polish reform programs, as in other European countries, are driven by an instrumental view of the university, while the logic of possible developments suggested by the Polish academic community is traditional and institutional. Powerful tensions related to the new reforms have their roots in the instrumental/institutional divide. In Poland, as opposed to Western European systems, it was the academically-driven institutional logic in the last two decades that seems to have deinstitutionalized the research mission in public universities. It is with the new institutional logic of the recent reform package that the research mission can be reinstitutionalized in top research universities (but under new conditions and guided by strict national priorities). Surprisingly, the traditional research mission seems to have only recently been defended by policymakers and their instrumental views of the university. The traditional institutional view of the university represented by the Polish academic community in soft academic disciplines was unable to maintain the growth in university knowledge production at levels comparable to those of its regional competitors, as the empirical part of this paper shows.

\section{Conclusions}

This paper places recent higher education reforms in Poland in the wider context provided by the changing codes of academic behavior which led to the lack of balance between major university missions: the exaggerated teaching focus and the devalorization of research. Polish universities are therefore increasingly viewed by policymakers from an instrumental, rather than institutional, higher education policy perspective and one of the reasons is the perceived failure of the institutional view (and especially the view of the university as a 'rule-governed community of scholars') in leading to growth in internationally visible (and internationally measured) knowledge production. As elsewhere in Europe, Polish reforms rationalize universities as organizations and are leading to their gradual construction as ever more formal organizations (rather than socially-rooted, traditional, and distinct institutions, see Brunsson and Sahlin-Andersson 2000). New legislation brings about the revalorization of the research mission of most prestigious public universities, massively abandoned in the expansion era (1990-2005), especially in soft disciplines in which the rapid growth of enrollments occurred and in which private higher education was concentrated. In the contraction era (in which the number of students is expected to decrease by $30 \%$ by 2025), a return to the traditional balance between teaching and research engagement is expected.

The new law on higher education seems to be saying goodbye to the deinstitutionalization processes of research engagement of Polish universities, as documented in this paper, and to be guiding them to become substantially more research-intensive. From the perspective of two decades, the recent legal change originating from a new, instrumental vision of the university, is interpreted as the reinstitutionalization of the research mission of Polish universities, or as a passage from one normative and institutional order to another. The empirical data show that in the currently divided academy, the passage to a new order introduced by new higher education and research legislation may be much more difficult for the academic community from those fields which were massively expanded in both public and private sectors. As in the case of any public sector reforms, there will be institutional (and individual academic) winners and losers in the process of bringing research activities back to universities through new governance and funding mechanisms. It is hard to 
predict the outcomes knowing that, as observed in organizational research by Olsen (1998: 322) 15 years ago:

...decisions to change often do not lead to change, or they lead to further unanticipated or unintended change. Institutional reforms breed new demands for reforms rather than making reforms redundant.

\section{Acknowledgements}

The author gratefully acknowledges the support of the Polish National Research Council (NCN) through its grant DEC-2011/02/A/HS6/00183. The author also wishes to thank the anonymous editorial reviewers for their valuable comments to an earlier draft of the paper.

\section{Notes}

1. In terms of the total number of full-time equivalent researchers in Poland in 2000 there were about 34,000 researchers in the higher education sector and about 11,000 researchers in the government sector. In the higher education sector, compared to Poland, there were about six times less researchers in Hungary, seven times less in Slovakia and nine times less in the Czech Republic. In the government sector, the differences were equally marked: about four times less in Slovakia, and 2.5 times less in both Hungary and the Czech Republic (Eurostat 2012).

2. The EUROAC research project ('The Changing Academic Profession in Europe: Responses to Societal Challenges', 2009-12) was run for seven European countries, coordinated by Ulrich Teichler of Kassel University and funded by the European Science Foundation. Its Polish component included about 4,000 returned surveys and 60 interviews and was coordinated by the present author (the team also included Dr. Dominik Antonowicz).

3. The EUROAC question was Question B2: 'Regarding your own preferences, do your interests lie primarily in teaching or in research?' (EUROAC project database, January 2012, University of Kassel; the count (n) was generally 900-1,500 academics per country studied, and was much higher (above 3,500) for Poland).

\section{References}

Aghion, P., Dewatripont, M., Hoxby, C., Mas-Collel, A. and Sapir, A. (2008) Higher Aspirations: An Agenda for Reforming European Universities. Brussels: Breugel.

- (2009) 'The governance and performance of research universities: Evidence from Europe and the U.S', NBER Working Paper No. 14851. Cambridge, MA: National Bureau of Economic Research.

Bonaccorsi, A. and Daraio, C., eds, (2007) Universities and Strategic Knowledge Creation. Specialization and Performance in Europe. Cheltenham, UK: Edward Elgar.
Bonaccorsi, A. and Simar, L. (2007) 'Efficiency and productivity in European universities: Exploring trade-offs in the strategic profile'. In: Bonaccorsi, A. and Daraio, C. (eds) Universities and Strategic Knowledge Creation. Specialization and Performance in Europe, pp. 144-207. Cheltenham, UK: Edward Elgar.

Brunsson, N. (2009) Reform as Routine. Organizational Change and Stability in the Modern World. Oxford, UK: OUP.

Brunsson, N. and Sahlin-Andersson, K. (2000) 'Constructing organizations: The example of public sector reform', Organization Studies, 21: 721-46.

Brunsson, N. and Olsen, J. P. (1993) The Reforming Organization. Copenhagen: Fagbokforlaget.

Clark, B. (1987) The Academic Life. Small Worlds, Different Worlds. Princeton, NJ: Carnegie Foundation for the Advancement of Teaching.

Deephouse, D. L. and Suchman, M. (2008) 'Legitimacy in organizational institutionalism'. In: Greenwood, R., Oliver, C., Suddaby, R. and Sahlin, K. (eds) The Sage Handbook of Organizational Institutionalism, pp. 49-77. London: Sage.

Dill, D. D. and Van Vught, F. A., eds, (2010) National Innovation and the Academic Research Enterprise. Public Policy in Global Perspective. Baltimore, MD: Johns Hopkins University Press.

Djelic, M.-L. and Quack, S. (2008) 'Institutions and transnationalization'. In: Greenwood, R., Oliver, C., Suddaby, R. and Sahlin, K. (eds) The Sage Handbook of Organizational Institutionalism, pp. 299-323. London: Sage.

Eurostat. (2012), <http://epp.eurostat.ec.europa.eu/portal/page/ portal/eurostat/home/> accessed 10 April 2012.

Gómez-Núnez, A. J., Vargas-Quesada, B., de Moya-Anegón, F. and Glänzel, W. (2011) 'Improving SCImago Journal and Country Rank (SJR) subject classification through reference analysis', Scientometrics, 89: 741-58.

Kwiek, M. (2006) The University and the State. A Study into Global Transformations. New York: Peter Lang.

- (2007) 'The university and the welfare state in transition. Changing public services in a wider context'. In: Epstein, D., Boden, R., Deem, R., Rizvi, F. and Wright, S. (eds) Geographies of Knowledge, Geometries of Power: Framing The Future of Higher Education, pp. 32-50. New York: Routledge.

- (2008) 'Accessibility and equity, market forces and entrepreneurship: Developments in higher education in Central and Eastern Europe', Higher Education Management and Policy, 20: 89-110.

. (2010) 'Creeping marketization: Where Polish private and public higher education sectors meet'. In: Brown, R. (ed.) Higher Education and the Market, pp. 135-45. New York: Routledge.

- (2011a) 'The public/private dynamics in Polish higher education: Demand-absorbing private growth and its implications', Higher Education Forum, 8: 37-59.

- (2011b) 'Universities and knowledge production in Central Europe'. In: Temple, P. (ed.) Universities in the Knowledge Economy. Higher Education Organisation and Global Change, pp. 176-95. New York: Routledge.

—. (2012a) 'Universities, regional development and economic competitiveness: The Polish case'. In: Pinheiro, R., Benneworth, P. and Jones, G. (eds) Universities and Regional Development. A Critical Assessment of Tensions and Contradictions, pp. 69-85. New York: Routledge.

- (2012b) Knowledge Production in European Universities. States, Markets, and Academic Entrepreneurialism. New York: Peter Lang (forthcoming).

Lepori, B., Benninghoff, M., Jongbloed, B., Salerno, C. and Slipersaeter, S. (2007) 'Changing models and patterns of 
higher education funding: Some empirical evidence'. In: Bonaccorsi, A. and Daraio, C. (eds) Universities and Strategic Knowledge Creation. Specialization and Performance in Europe, pp. 85-111. Cheltenham, UK: Edward Elgar.

Maassen, P. and Olsen, J. P., eds, (2007) University Dynamics and European Integration. Dordrecht, the Netherlands: Springer.

March, J. and Olsen, J. P. (1989) Rediscovering Institutions. The Organizational Basis of Politics. New York: Free Press.

. (2006a) 'The logic of appropriateness'. In: Moran, M., Rein, M. and Goodin, R. E. (eds) The Oxford Handbook of Public Policy, pp. 689-708. Oxford, UK: OUP.

-. (2006b) "Elaborating the "New Institutionalism". In: Rhodes, R. A. W., Binder, S. A. and Rockman, B. A. (eds) The Oxford Handbook of Political Institutions, pp. 3-20. Oxford, UK: OUP.

Neave, G. and van Vught, F. A., eds, (1991) Prometheus Bound. The Changing Relationship Between Government and Higher Education in Europe. Oxford, UK: Pergamon Press.

Neave, G. and van Vught, F. A., eds, (1994) Government and Higher Education Relationships across Three Continents. The Winds of Change. Oxford, UK: Pergamon Press.

Oliver, C. (1992) 'The antecedents of deinstitutionalization', Organization Studies, 13: 563-88.

Olsen, J. P. (1998) 'Institutional design in democratic contexts'. In: Brunsson, N. and Olsen, J. P. (eds) Organizing Organizations, pp. 319-49. Copenhagen: Fagbokforlaget.

- (2007) 'The institutional dynamics of the European university'. In: Maassen, P. and Olsen, J. P. (eds) University Dynamics and European Integration, pp. 25-54. Dordrecht, the Netherlands: Springer.
(2008) 'Change and continuity: An institutional approach to institutions of democratic government', ARENA Working Paper No. 18. <http://www.arena.uio.no > accessed 9 January 2012.

. (2010) Governing through Institution Building. Institutional Theory and Recent European Experiments in Democratic Organization. Oxford, UK: OUP.

Olsen, J. P. and Maassen, P. (2007) 'European debates on the knowledge institution: The modernization of the university at the European level'. In: Maassen, P. and Olsen, J. P. (eds) University Dynamics and European Integration, pp. 3-24. Dordrecht, the Netherlands: Springer.

Palfreyman, D. and Tapper, T. (1999) Oxford and the Decline of the Collegiate Tradition. New York: Routledge.

Peters, B. G. (1999) Institutional Theory in Political Science. The 'New Institutionalism'. London: Continuum.

Pfeffer, J. and Salancik, G. R. (2003) The External Control of Organizations. A Resource Dependence Perspective. Stanford, CA: Stanford University Press.

Porter, M. E., Sala-i-Martin, X. and Schwab, K. (2008) The Global Competitiveness Report 2007-2008. New York: Palgrave.

Scott, W. R. (2008) Institutions and Organizations. Ideas and Interests, 3rd edn. Thousand Oaks, CA: Sage.

Tandberg, D. A. (2010) 'Politics, interest groups and state funding of public higher education', Research in Higher Education, 51: 416-50.

Wolszczak-Derlcz, J. and Parteka, A. (2010) Scientific Productivity of Public Higher Education Institutions in Poland. A Comparative Bibliometric Analysis. Warsaw: Ernst and Young. 